\title{
Forestry-Wildlife: Whither the Future
}

\section{F. L. BUNNELL}

Faculty of Forestry, University of British Columbia, Vancouver, B.C. V6T 1W5

\begin{abstract}
Conditions in areas with higher ratios of people to trees than North America suggest changes in North American perspectives of forestry-wildlife relations. These conditions, as they were presented at a recent IUFRO meeting, are summarized. Implications of these conditions for North America are that our forestry-wildlife problems will acquire an increasing social dimension, while solutions will become increasingly varied and complex. The old-growth forests still present in North America will permit a degree of flexibility in management now lacking in much of Europe.
\end{abstract}

\section{Introduction}

Much has been written about the relationship between forestry practices and wildlife numbers. The majority of the early writers optimistically argued that "good" forestry practices were "good" for wildlife, usually on the basis of ingenuous faith in the term "good" with little supportive data (Gabrielson 1936; Morton 1936; Cahalane 1939; De Vos 1949). Gradually, documented cases of conflict accumulated (Adams 1949; Adams et al. 1949; Davenport 1941; Huestis 1955) and published reports acquired a more unilateral perspective (Dodge
1959; Grisez 1959). Over the last few years the trend has again shifted, and reports addressing joint forestry-wildlife management systems but incorporating data have begun to appear (Thomas et al. 1975; Bunnell and Eastman, in press). Here I wish to consider the future and offer some predictions about forestry-wildlife relations 10 to 50 years from now.

I will develop my predictions by considering recent discussions held by IUFRO Working Party S1. 08-01 "Effects of forest management and practices on wildlife" in Istanbul and Ankara, Turkey, September, 1975. The value of presenting these discussions is that the more global view of IUFRO helps to place North American concerns about forest-wildlife relations into a broader perspective and thus facilitates contemplation of the future. The predictions offered are based upon evaluation of this global overview relative to conditions in North America.

\section{Forestry-wildlife: a global view}

To provide a broad perspective I have summarized discussions of the recent IUFRO working sessions. Participants in the sessions came from Algeria, Canada, Switzerland, the United Kingdom, West Germany, and Yugosalvia. As expected, the socio-economic conditions prevailing in each participant's country strongly moulded the opinions and concerns he expressed. The diversity of socioeconomic conditions, combined with the broad definition of wildlife, produced a "broad palette of colors" but hardly allow me "to paint a general picture."

\section{Algeria}

Algeria's forest-wildlife problems are essentially two-fold: 1) damage by insects (wildlife within the IUFRO definition) and 2) overgrazing by domestic stock. The wildlife species causing the most concern is a caterpillar (the processionary worm or Pythiocampa processionea) which is indigenous but recently has proven particularly devastating in the large monocultures of Pinus halipennsis. The second problem, domestic over-grazing by sheep and goats which virtually eliminates regeneration, is a social problem; the indigenous people, some settled and some nomadic, view it as their right to graze public land. In this respect, the problems of Algeria and Turkey (and British Columbia, for that matter) are similar. The problem is neither biologically nor technically based since the same individuals who run their stock over public land do fence their own gardens quite effectively. 


\section{United Kingdom}

In marked contrast to Algerian concern for effective insect control are the comprehensive efforts of the British Nature Conservancy to maintain all wildlife including insects in their forested Nature Reserves. Participants from the United Kingdom cited examples in which the forest management system was developed to help maintain butterfly populations (the black hairstreak, Strymonidea pruni, in Monk's Wood and the heath fritillary, Melatea athalia, in Blean Woods). Such efforts to manage forests for wildlife populations are not limited to insects, nor is wildlife consistently encouraged in the United Kingdom. Browsing by red and roe deer, and peeling by red deer, are common problems in British forests and efforts are being made to control the dispersal of red deer in Scotland primarily because of fear of damage to forests.

\section{Central Europe}

The Swiss participant was much concerned over the reduction in bird diversity associated with pure or even-aged stands. To a considerable extent his approach is an expression of the "naturalist" principle propounded by Swiss silviculturists, but with particular emphasis on birds. He also noted heavy local browsing and peeling damage by roe and red deer, and felt that this damage also was a problem of pure stands. Unfortunately, the same "naturalist" principle which frequently encourages mixed species forests in Switzerland also encourages deer populations of sufficient density that damage to forest trees is an inevitable consequence.

The concern over deer (in particular red deer) feeding was a theme continued by participants from Germany and Yugoslavia. Wildlife damage problems in Yugoslavia are becoming so great that forest managers intend to eliminate red deer from some forested areas; that is, "multiple use" is not working. Decisions concerning alternative uses in Yugoslavian forests are particularly difficult because trophy hunting by foreigners is a profitable enterprise. The resulting dilemma has led the Yugoslavian participant to shift his research interest to "recreation" and assessment of public desires to help evaluate potential tradeoffs. Actual physical impact of browsing appeared best documented in Germany. Figures presented on the causal agents damaging commercial tree species in southwestern Germany indicated that game animals caused $75 \%$ of the economic damage. In this same area, spruce (Picea abies) in fenced enclosures averaged $62 \mathrm{~cm}$ taller than unfenced spruce after 4 years of growth. These phenomena have produced a situation where fall treatment of all young trees with a tar repellent is common. Current findings suggest that for spruce there is almost complete recovery to normal growth 10-15 years after escape from browsing. Bark-peeling, of course, is far more detrimental and may extend to $50 \%$ or more of stands $10-60$ years of age. The effects of browsing on deciduous species is greater, occasionally leading to complete elimination of regeneration and a shift in species composition of the forest. These latter observations were confirmed to be applicable in Austria and Switzerland as well.

\section{Whither the Future}

The foregoing points allow one to place North American concerns into sociological and time perspectives which suggest specific changes. I will present my predictions about these impending changes simply and briefly.

\section{The global village}

All forest wildlife problems mentioned at the IUFRO meetings have their analogies in North America. The Algerian nomad's assumption of grazing rights on public lands is very little different from the British Columbia rancher's. The Swiss forester's concern about the lack of diversity in pure spruce stands reducing bird diversity is little different from local concerns that alder eradication and the planting of Douglas-fir reduces some warbler populations. Similarly, the spruce budworm and processionary worm are obvious analogies.

\section{Presently flexible, but...}

Relative to other areas of the world, in North America our remaining stands of old growth offer us considerable flexibility in forest-wildlife management. We have the special features of old growth forest resident on the stump and do not need to approximate these features through particular management of plantation forests. Whereas in the Pacific Northwest we argue about the magnitude of old growth areas which should be set aside as winter range for a healthy and abundant species (e.g. black-tailed deer), the Indian Government must decide the fate of the Gir forest, the refuge of the last 200 Asian lions, but which provides no food input to increasing human populations. As our old growth and flexibility diminish, arguments between opposing interest groups will likely become increasingly acrimonious or, more sadly, quietly resigned.

\section{Next time, single use?}

More intensive resource management means single use. Although the central European nations have a relatively long history of "Wald und Wild" they never adopted "multiple use" with the full robust flavor that at one time (perhaps still) holds true in parts of North America (Clarke 1958, 1965; Behan 1967; Shaw 1967). I find this more conservative attitude telling. North Americans proclaimed the joys of multiple or integrated use often within an environment where very intensive use of any single resource was unknown. A flexibility now long vanished from many European forests was present. Central Europe was already experiencing the tension of intensive use and limited flexibility primarily because the ratio of people to trees was much higher. 
In central Europe, "multiple use" management consists of protecting the trees with repellents and fences and maintaining the ungulates with winter feeding and controlled harvests - all at considerable cost. I sense a departure from the "naturalist" principle which will lead to an acknowledged and planned mosaic of single uses, not one invoked by deer fences. It is perhaps more telling that gradual acknowledgement of the difficulties of "multiple use" (sensu North America) have occurred in Europe while in many regions of North America we still pursue the concept energetically.

\section{New approaches}

I anticipate that for several decades the flexibility we do have in North America and perhaps Fennoscandia will permit us to achieve a mosaic of single, or at least predominant, uses on a different scale than in Europe. In regions where wood fibre production is judged critical, we will likely marshal sufficient capability to eliminate most "detrimental" wildlife from high-site lands. Conversely, we will probably pursue effective gameranching of ungulates in other areas (Telfer and Scotter 1975). Social acceptance will not be rapid, but neither will it be totally recalcitrant. There will be two further broad approaches to forests and wildlife. In many areas we will struggle with the costly tensions - protecting the wildlife from the forestry practices and the trees from the wildlife. In a few areas we will see forestry of a very special nature, not erecting nest boxes but generating a specific structure and composition, perhaps snags for woodpeckers. Management of the Michigan pine barrens for Kirtland's warblers is a current example.

\section{Social roots}

Everywhere the greatest problems in land use have deep social, economic or political as well as biological or technical roots. The B.C. rancher running cattle on forested, game winter-range and the Turkish shepherd illegally burning once productive coppice again are examples. In this respect exchange of biologically based research findings through organizations such as IUFRO are only a first step, perhaps explaining the obvious. I anticipate the appearance of experienced managers and possibly social scientists among such groups and hope their appearance prophesies effective contribution.

\section{Remembering the future}

Resource managers are frequently accused of being myopic in their vision of the consequences of particular management activities. They are accused of not remembering the future when they plan such activities because consequences several decades away are either neglected or not fore- seen. If my predictions about the future of forestrywildlife relations are correct, it is worthwhile remembering some of these in our anticipation of the future. There are two points I wish to emphasize.

First, it is clear that our management "problems" have social as well as biological roots. Similarly, it is reasonable to expect that as the ratio of people to trees increases so will the significance of social aspects of resource management. In our education of foresters, formulation of task forces and considerations of professional conduct it almost certainly will be worthwhile remembering this aspect of our future. The second point is simply that we can anticipate an enormous increase in the complexity of forestry as we attempt to accommodate wildlife interests and damage. I have addressed this matter more fully in my consideration of the myth of the omniscient forester (Bunnell 1976). Here I simply wish to emphasize that complexity is another aspect of our future which we should not forget.

\section{References}

Adams, L. 1949. The effects of deer on conifer reproduction in Northwestern Montana. J. Forest.: 909-913.

Adams, L., M.G. Hanavan, N.W. Hosley and D.W. Johnstone. 1949. The effects on fish, birds and mammals of DDT used in the control of forest insects in Idaho and Wyoming. J. WildI. Manage. 1:245-254.

Behan, R.W. 1967. The Succotash Syndrome, or multiple use; a heartfelt approach to forest land management. Nat. Resources J. 87:473-484.

Bunnell, F.L. 1976. The myth of the omniscient forester. For. Chron. 52:150-152.

Bunnell, F.L. and D.S. Eastman. (in press). Effects of forest management practices on wildlife in the forests of British Columbia. Intern. Union of Forest Research Organizations. XVI Congress Proc.

Cahalane, V.H. 1939. Integration of wildlife management with forestry in the Central States. J. For. 37:162-167.

Clarke, C.D. 1958. Wildlife in the forest. For. Chron. 34:7-12.

Clarke, C.H.D. 1965. Wildlife values in forestry in Ontario. For. Chron. 41:237-244.

Davenport, L.A. 1941. Timber vs. wildlife. J. Forest. 39:661-666.

De Vos, A. 1949. Correlation between game and forest management. Sylva 5:29-34.

Dodge, W.E. 1959. An effective poison and repellent for porcupine control. J. For. 57:350-352.

Gabrielson, I.N. 1936. The correlation of forestry and wildlife management. J. For. 34:98-103.

Grisez, T.J. 1959. A low cost deer fence. J. For. 57:42-43.

Huestis, E.S. 1955. The effects of logging old-growth timber on big game. Proc. Soc. Amer. Foresters: 123-124.

Morton, J.N. 1936. Wildlife: an important forest product. J. For. 34:40-45.

Shaw, S.P. 1967. Woodlots, wildlife and timber management. Trans. N. Am. WildI. Conf. 32:238-246.

Telfer, E.S. and G.W. Scotter. 1975. Potential for game ranching in boreal aspen forests of western Canada J. Range Manage. 28:172-180.

Thomas, J.W., G.L. Crouch, R.S. Bumstead and L.D. Bryant. 1975. Silvicultural options and habitat values in coniferous forests. pp. 272-287 In: Proc. of Symposium on Management of Forest and Range Habitats for Habitats for Nongame Birds. U.S.D.A. For. Ser. Gen. Tech. Rept. WO-1, $343 \cdot p$. 